\title{
An empirical examination of the influencers of premature decline of African clusters: Evidence from textile clusters in Ghana
}

\begin{tabular}{|c|c|}
\hline \multicolumn{2}{|c|}{$\begin{array}{l}\text { Authors: } \\
\text { Lydia Asare-Kyire }^{1} \text { (1) } \\
\text { He Zheng }{ }^{1} \text { (1) } \\
\text { Ackah Owusu }^{2} \text { (] }\end{array}$} \\
\hline \multicolumn{2}{|c|}{$\begin{array}{l}\text { Affiliations: } \\
{ }^{1} \text { School of Management and } \\
\text { Economics, University of } \\
\text { Electronic Science and } \\
\text { Technology of China, China }\end{array}$} \\
\hline \multicolumn{2}{|c|}{$\begin{array}{l}{ }^{2} \text { Nobel International Business } \\
\text { School, Ghana }\end{array}$} \\
\hline \multicolumn{2}{|c|}{$\begin{array}{l}\text { Corresponding author: } \\
\text { Ackah Owusu, } \\
\text { ackah_owusu@yahoo.com }\end{array}$} \\
\hline \multicolumn{2}{|c|}{$\begin{array}{l}\text { Dates: } \\
\text { Received: } 28 \text { July } 2017 \\
\text { Accepted: } 01 \text { June } 2018 \\
\text { Published: } 28 \text { Feb. } 2019\end{array}$} \\
\hline \multicolumn{2}{|c|}{$\begin{array}{l}\text { How to cite this article: } \\
\text { Asare-Kyire, L., Zheng, H., \& } \\
\text { Owusu, A. (2019). An } \\
\text { empirical examination of the } \\
\text { influencers of premature } \\
\text { decline of African clusters: } \\
\text { Evidence from textile clusters } \\
\text { in Ghana. South African } \\
\text { Journal of Business } \\
\text { Management 50(1), a318. } \\
\text { https://doi.org/10.4102/ } \\
\text { sajbm.v50i1.318 }\end{array}$} \\
\hline \multicolumn{2}{|c|}{$\begin{array}{l}\text { Copyright: } \\
\text { (C) 2019. The Authors. } \\
\text { Licensee: AOSIS. This v } \\
\text { is licensed under the } \\
\text { Creative Commons } \\
\text { Attribution License. }\end{array}$} \\
\hline \multicolumn{2}{|c|}{ Read online: } \\
\hline 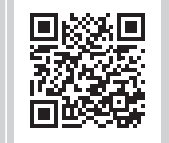 & $\begin{array}{l}\text { Scan this QR } \\
\text { code with your } \\
\text { smart phone or } \\
\text { mobile device } \\
\text { to read online. }\end{array}$ \\
\hline
\end{tabular}

Background: Comparatively, industry clusters in Africa have retrogressed over the years while their counterparts in Asia, Europe and America serve as engines for innovation and economic development. The textile industry cluster in most African economies has been threatened and is negatively affecting productivity, employment and revenue generation. Their survival, growth and sustainability are critical because of the sector's contribution to national development

Objective: In this ariticle we investigate the role fators such as stakeholder relation among actors in the textile ecosystem, influence of supply chain networks, third-party pressures and technological changes affected the development of textile clusters in Ghana and how the country can rebuild the clusters.

Method: Using partial least-square structural equation modelling techninque, we tested theoritical hypotheses using survey data from firms in the industrial enclave of Ghana.

Result: The findings from the study acknowledges a sharp decline in the productivity and performance of firms in various industrial sectors especially the textile cluster. The influx of copycat products coupled with the firm's inability to adapt to changing production technology have been a key influencer in the deteriorating state of the textile industries. Again, gaps in stakeholder interactions and underutilised supply chain networks create bottlenecks that hinder the competitiveness and performance of these enterprises.

Conclusion: On the contrary, findings from our study suggest external pressure from donors, multinationals and political influencers do not affect the performance and competitiveness of the textile sector as suggested by previous studies. Resuscitating the industry sector requires deliberate effort to improve coordination, information and technology sharing between key actors.

\section{Introduction}

Industry clusters have played a significant role in the development of both regional and national development in past decades (Sturgeon, 2003; Sturgeon et al., 2008). For instance, Silicon Valley and the San Diego Biomedical Cluster in the USA, Brits Valley in Tokyo, Bangalore in India and the Zhongshan Gas Appliance cluster in China contribute greatly towards the socio-economic development of their individual economies. In addition to enhancing various economies, they contribute towards the enrichment of the global value chain as well as improving the standard of living of a region's citizenry (Bankova, 2015; He \& Rayman-Bacchus, 2010; Matton \& Wang, 2014; Saxenian, 1996). An industry cluster refers to a geographical concentration of interconnected firms, upstream and downstream customers and other supporting institutions (Gulati, 1995; Krugman, 1991; Kurniawan, Abdullah, Som, \& Parasuraman, 2013; Mowery, 2009; Porter, 2000; Xingang et al., 2016). The geographical proximity of a firm is a critical factor in the success of firms in an industry cluster as that enables the transfer of knowledge and information between firms and other related agents (Schmitz \& Nadvi, 1999; Tao \& Forman, 2016; Tsai, Yeh, Wu, \& Huang, 2005). The continuous interaction between actors within a particular geographical location leads to the establishment of some form of social network. The establishment of such a network is backed by the constant sharing of knowledge and information among parties. Social ties are improved significantly during these interactive sections (Gereffi et al., 2016; Gordon et al., 2000; Morosini, 2003). When knowledge and information are shared, it results in the development of new improved products and processes that are of high value and quality (Freeman, 2002; World Development, 1999). In addition, there exists a high diffusion rate of innovation among actors in this ecosystem because of the embedded characteristics, which enhance trust and tacit 
understanding between members in an ecosystem (Weng, 2016a; Xingang et al., 2016).

The absorptive capabilities of firms is improved through frequent exchanges and this explains why firms within an industry cluster are more innovative and competitive than firms found outside the cluster (Cortright, Sandhof, \& Basilio, 2006; Ganesan et al., 2005; Lindberg \& Säll, 2013; Porter, 2000; Wong, 2013). Empirical evidence by Prim et al. (2016) proves that a significant source by which firms can generate innovation, competition and sustenance is through agglomeration economies of a cluster. The operational patterns of clusters have the flexibility in adjusting to uncertain business transformations (Borrus, 2000; Purwanto et al., 2015) and may explain why cluster entities that are not properly connected fail (Bankova, 2015; McCormick, 1998).

An industrial cluster generally goes through four stages: emergence, growth, maturity and decline or renewal phases in its life cycle (Amélia \& Lopes, 2013; Menzel \& Fornahl, 2009). However, not all clusters are able to exhaust their life span (Amélia \& Lopes, 2013). A cluster may fail in its ability to withstand a fluctuating environment and this could force the cluster to decline prematurely. As Weng (2016b) suggests, the moment information asymmetry is experienced in a cluster, its atmosphere of innovation may cease to spread without positive feedback. In addition, the cluster may encounter challenges in product innovation because of new competitive ideas, opportunities and technology that could exert pressure on the cluster to decline. Menzel and Fornahl (2009) attribute the evolution of clusters to their qualitative (external environmental factors and the internal forces at work) and quantitative aspects (the number of firms and their employees), and their ability to move to the next phase is determined by the context in which they arose. When these qualitative and quantitative features are not in favour of the cluster and happen unexpectedly, they become a shock to the cluster and push it into a release phase, where the cluster diminishes in scope and most firms fold (Martin \& Sunley, 2011). Then the cluster's survival would depend on its capability to adapt to the changing trends and renovate. According to Spencer, Vinodrai, Gertler and Wolfe (2010), firms located in clusters do have a greater advantage with efficient network distribution and are able to achieve higher returns than non-clustered ventures, but in the absence of a collaborative network, clusters become ineffective, experience high production costs, are not able to withstand business revolutions and may decline prematurely (Bankova, 2015; Borrus, 2000; Kirankabeş \& Arik, 2014; McCann et al., 2016; Sturgeon et al., 2008).

In Africa the concept of industry clusters has been implemented to augment the development of national innovation and industrialisation, with evidence from established clusters in Kenya, Uganda and Ghana, to mention a few, in line with industry development policies of such economies (McCormick, 1998). In Ghana, different clusters have been established in areas such as metalworks and manufacturing fabrication, and diverse industrial zones.
These clusters are both natural and policy-oriented clusters and have contributed to the development of their localities through job creation, increasing household incomes and substituting imports (Abor \& Quartey, 2010; Adikorley, 2013; Ahwireng-Obeng, 2000). In spite of the various benefits accrued to clustering, most clusters have declined in Africa, and Ghana in particular, in terms of productivity and employment. Mention can be made of the timber and textile clusters in Ghana (UNU-Wider, 2015). We are particularly concerned about the textile clusters because the once-vibrant industry, which was expected to diversify the economy and contribute to GDP, employment, incomes and foreign exchange, now behaves like a 'toothless $\mathrm{dog}^{\prime}$ or one who is helpless without knowing the way forward but only looking on and continuing to dwindle. The decline has been so sharp and steep that the general secretary of the Industrial and Commercial Workers' Union lamented that 'the textile industry is at the brink of collapse' (Ghana Web, 2017a). Similarly, the chief executive officer of a financial institution in Ghana claimed the ' $[t]$ extile industry is in dire straits' (Ghana Web, 2017b). This disturbing issue has caught the attention of the general citizenry as well as various researchers (Bruce-Amartey et al., 2014; Quartey \& Abor, 2011), because from all indications, it has passed the initial stage, which is characterised by shocks as a result of external influence, and was expected to be in its second stage, where it should be driven by labour market pooling, supply of intermediate and finished products as well as knowledge spillovers (Quartey, 2006). What might have influenced the textile cluster's premature decline at the period when the nation expected it to expand and perform its role as an engine of growth?

This research attempts to examine the extent to which some factors might have impacted the textile clusters, causing their premature decline, and how best the country can recover and sustain the clusters to ensure economic growth and development. In this article, we aim at empirically examining how factors such as stakeholder relation among actors in the textile ecosystem, influence of supply chain networks, thirdparty pressures and technological changes affected the development of textile clusters in Ghana and how the country can rebuild the clusters. Notwithstanding the immense contribution of industry clusters to the development of the micro- and macro-environment of firms and their locality, there happens to be no literature examining the determinants that led to the premature decline of textile clusters in Ghana. The choice of Ghana as a sample in Africa is because most clusters in the subregion share similar characteristics, and our findings and recommendations may provide some insights to the subregion as a whole. In addition, most clusters in Africa have been experiencing almost the same growth rate in past decades (McCormick, 1998; McCormick, Mitullah, \& Manga, 2007). The findings from the study acknowledge the decline of the sector and further outline how the inability of firms to adapt to changing technological trends to boost their competitive advantage, coupled with underutilised supply chain networks, creates several bottlenecks that hinders the performance of enterprise. Findings from the study suggest that external pressure from 
donors, multinationals and agencies do not affect the performance of the textile sector, which contradicts suggestions by previous studies.

This article is presented in five sections. Following this introduction is a presentation of the theoretical background and hypotheses. The next section focuses on the research methodology, with the section after that focusing on empirical analysis, discussion and implication. The final section concludes the study with some insightful recommendations in rebuilding and sustaining the clusters to avoid total collapse.

\section{Stakeholder relations and cluster sustenance}

Stakeholder relations are defined in this study as the interaction between various actors such as producers, upand downstream customers, suppliers in textilemanufacturing, distribution and the sales ecosystem. One critical factor that accounts for the success or failure of collective and individual organisational goals is the extent to which stakeholders interact (Freeman, Wicks, \& Parmar, 2004; Rapppaport, 1986; Rogers, 2003; Wood \& Jones, 1995). Stakeholders are comprised of varied individuals or a group of people who are affected by the actions of the firm or have the power to affect an organisation in accomplishing its set objectives (Eisenhardt, 1989; Freeman, 1984, 2004; Pfarrer, 2010). According to stakeholder theory, the micro- and macroenvironments of any organisation require the effort of all stakeholders to enhance its activities and survival (Brower \& Mahajan, 2013; Harrison \& Weaver, 2013). The availability and interaction of these actors aid in generating social capital that is necessary to enrich the outcome of firm activities (Boudreau, 2009; Burt, 2000; Granovetter, 1973; Grunig \& Huang, 2000). Social capital mainly focuses on the value of the social network that binds people and organisations with similar or diverse perspectives through norms of reciprocity increases because of the fact that each actor presents its own unique resources that can be utilised by other firms (Dekker \& Uslaner, 2001). In order to create value, it is a prerequisite for firms to have the required capacity to absorb the available social capital, hence the need to develop stakeholder interactions. In accordance with stakeholder theory, managers are to be coherent in the values they create as that determines the togetherness of principal stakeholders and the ability of the firm to pursue its set targets (Freeman, 1984); this article argues that the extent of the relationship between various stakeholders within the textile industry is critical to achieving set objectives. Scholarly studies suggest the interaction between stakeholders in any particular industry has a propensity to affect the sustainability of that particular sector (Antonacopoulou \& Meric, 2005; Choi \& Wang, 2009; Donaldson \& Preston, 1995; Dyer \& Singh, 1998; Freeman, 1984; Freeman \& Reed, 1983; Freeman et al., 2004; Garvare \& Johansson, 2010; Hillman \& Kein, 2001).

The textile cluster is comprised of various actors from cotton producers and processors, textile producers through to the final consumer and other governmental and non-governmental bodies with the aim of promoting textile production and consumption in the country. According to Wang and Sengupta (2016) and Hillebrand et al. (2015), the relationship existing between and among actors determines the extent to which a production unit can perform in a competitive market and be sustainable. Therefore to achieve high production and sustenance of the textile sector, it is prudent to ensure there is sufficient interaction between the individual members. When there is a cordial relationship between actors it fertilises the ground and breeds trust. Trust is an essential component if a set target among the various stakeholders can be attained (Gulati \& Nickerson, 2008). Cliques that have high trust rates have a high probability of sharing relevant information among members. In addition, it enhance information exchange, knowledge sharing and communication processes (Galaskiewics, 1995a; Zander \& Kogut, 1995). When actors do not trust each other, it limits the amount of information shared, resulting in information asymmetry or dissemination of inaccurate information, which affects firms' decision-making because such decisions are not grounded on factual data (Scandelius \& Cohen, 2016). When stakeholder relation with this complex ecosystem is porous, it leads to the creation of structural holes, as advocated by Burt $(1992,2014)$. Interactions between firms in clusters take two-folds-between downstream and upstream actors. Upstream actors include suppliers and other entities that produce semi-finished products, whereas downstream actors involve distributors, retailers and customers. Hence, to achieve the sustainable development and growth of the textile industry it is essential that these groups interact in a well-coordinated manner, as lack of such interactions between actors results in non-performance of such organisations (Patel, Manley, Hair, Ferrell, \& Pieper, 2016). The continuous interaction among agencies enables smooth maintenance of cluster network as a whole. Stakeholders play a critical role in ensuring the sustainable growth of an economy (Shing, Chung, \& Crawford, 2016). Consequently there has been a surge in policies that target fostering interactions between various actors in an ecosystem (Coombs \& Holladay, 2007; Gruning \& Huang, 2000). Arguing from a network perspective, the interaction between agencies leads to actor-network embeddedness. When actors are embedded into a particular network it aids in understanding the merits of such a network and what its core mandate is. Again, when actors are well integrated into such a complex system they are able to identify and discover issues happening within a particular sector as compared to actors who are not interrelated in an ecosystem (Latour, 2005; Luoma-aho \& Vos, 2009; Rogers, 2003; Williamson, 1985; Wu, 2007).

In this study, the authors argue that although several researchers, such as McCormick, Gebre-Egeziabher and Kuzilwa (2009), McCormick (1998), Mytelka and Oyelaran Oyeyinka, 2011; Mytelka, 2000; Oyelaran-Oyeyinka and McComick (2007) and Page (2012), have studied innovation and cluster performance in Africa, there is limited understanding as to how stakeholder relationships affect the sustainability of clusters in Africa. In examining stakeholder 
engagements and the sustainability of the textile firms, we propose that:

$\mathbf{H}_{1}$ : The interaction between upstream and downstream stakeholders within the textile industry has the propensity to negatively affect the growth of the local textile cluster.

\section{Technological changes and cluster sustenance}

Technological innovation is the catalyst for economic growth and development (Perez, 2009; Schumpeter, 1920, 1970). For a firm to survive, especially in a volatile, uncertain, complex and ambiguous business environment, it needs to be innovative. Being innovative to outwit competitors while enhancing its competitive advantage through uniqueness of products and ability to acquire a greater market share as compared to its competitors is one of the few ways to ensure longevity of enterprises in such an unpredictable environment (Horner, 2014; Pavlínek \& Žížalová, 2014; Porter, 2000; Volberda \& Van den Bosch 2005). Although innovation is the panacea for both organisational and economic growth (Schumpeter, 1970), firms in an industry cluster turn out to be more innovative comparatively because of several factors such as labour mobility and geographical proximity that stimulate the exchange of information, technology and knowledge sharing among firms (Chesnrough, 2003; Krackhardt \& Porter, 1986; Porter, 2000).

Most clusters in Africa have shrunk over the years as compared to their counterparts in developed and transition economies (Mano, Iddrisu, Yoshino, \& Sonobe, 2012; Page, 2012). Factors such as gaps associated with knowledge transfer, lack of capital and specialised human capital because of the low level of integration between clusters on this continent (McCormick, 1998) limit the amount of information and knowledge being shared among firms in the cluster. Some scholars argue the usage of information communication technology (ICT) can eliminate the physical barrier that impedes information and knowledge sharing between various business organisations (McCormick, Kinyanjui \& Ongile, 1999), but inferring from statistics on the penetration and utility rate of Internet suggests that the African continent has the lowest Internet penetration and usage rate in the world at $28 \%$ and $9.6 \%$, respectively (Otchere et al., 2013). Aside from the penetration rate, the ability of individuals to implement enterprise communication networks is capital intense and therefore not an ideal solution for small and medium enterprises, as most firms within clusters in Africa fall into this category (Mytelka, 2004; Oyelaran-Oyeyinka, 2001, 2011; Yosiho, 2010).

One critical factor hindering the development of these clusters is their inability to adapt to changes in technological trends (Perez, 2009; Scheel, 2002). This leads to a technological gap that affects the productivity of firms in this region, as they are unable to adopt and implement new production technologies to enrich their output and competitive advantages. It also affects an organisation's potential and realised absorptive capacity - the ability of an organisation to recognise, assimilate, value and utilise new external knowledge - as their access to new knowledge developed by other sectors is impeded (Brettel, Greve, \& Flatten, 2011; Jansen, Van Den Bosch, \& Volberda, 2005; Tsai, 2001).

The ripple effect of this situation deprives the firm of its ability to compete with foreign competitors, decreasing national export revenue (UNCTAD, 2001, 2003; UNIDO, 1999). Firms resort to corporate restructuring and downsizing in order to sustain their functional activities, as was done by a textile cluster in Ghana recently (Ghana Web, 2017), but in reality usage of obsolete technology decreases firms' production and performance while increasing overhead costs, which results in high budget deficits. For instance a textile firm (name withheld for privacy purposes) that used to produce over 10 million yards of fabric per year some years ago could not boast of 1 million yards per year as of 2016 (Agola, 2016).

In investigating whether or not a firm's inability to adopt to changing trends in technology and persistent usage of old production methods is a determinant in the failure of the textile clusters in Ghana, we formulate Hypothesis 2 as follows:

$\mathbf{H}_{2}$ : The persistent usage of obsolete production technology and equipment over the years has negatively affected the growth of local textile clusters.

\section{Third-party pressures and cluster sustenance}

Third-party pressure is defined as the terms and conditions that are mostly associated with grants and loans provided to firms and governments, especially in developing countries. Donor funds are a major source of developing capital for most governments in Africa. Obviously, the rapid infrastructural development in most African nations is attributed to funding from international donors and governments over the years. For instance in Ethiopia the Chinese government has funded the construction of the first light railway system. It is anticipated that this project will serve as productive grounds to boost the fortunes of the nation (Abuzeid, 2009; Agola, 2016). However, these aids and donor funds are most often attached to conditions that may have negative externalities and crowd out local enterprises in the long run (Kilby \& Dreher, 2010; Spencer, 2008; Zimmermann, 2005). The consequence is the inability to enact laws to protect local enterprises. It has been found in studies that the downside of international aid leads to exploitation of natural resources and underdevelopment of local manpower (McCormick et al., 2007; Zimmermann, 2005). When local firms do not acquire the right resources to build their capacity, they become non-competitive in both the local and global markets (Vitek 1999).

External political pressures in some cases influence the implementation of policies in the donor receiving partner 
(Osei, Baah-Nuakoh, \& Tutu, 1993; Yamin \& Sinkovics, 2008). For instance loan facility from the World Bank in 2009 to Ghana, had some intriguing conditions like freezing of public sector employment over a period of 3 years. The result of such conditions reduces the quality of human capital. Nonperforming manpower negatively affects the productivity of a nation (Freeman, 2008; Kurata, Matias, \& Grepo, 2015; McCormick, 1999; Sang, Guyo, \& Odhiambo, 2014). In addition to weakening human capital resources, it contributes towards an increase in poverty and reduces household income because individuals of employable age would be jobless (Sunkel, 1996).

This article argues that these external pressures hinder the growth of local firms, as receiving governments are not able to implement strict policies that will create an enabling environment and level the playing ground for both local and foreign businesses. On this, we hypothesise that:

$\mathbf{H}_{3}$ : The pressure from external agencies resulting from terms and conditions linked to donor funding and political entities has a negative impact on the performance of local textile firms

\section{Supply chain network and cluster sustenance}

The essential nature of supply chain networks in attaining firms' competitive advantage and increase in performance cannot be underestimated (Christopher, Peck, \& Towill, 2006). Well-oiled supply chain networks provide firms with the requisite capacity to enter new markets, compete and cooperate to enrich its revenue stream (Wu \& Chen, 2009). The performance of any supply chain network has an effect on the functional and behavioural activities of such an entity (Harland, 1996). Firms have purposefully integrated their supply chain and corporate strategies to enhance the individual firm's strategic positioning (Harland, 1996). Core competences and value creation are improved through the implementation of prudent measures (Akoten \& Otsuka, 2007; Narasimham \& Das, 2001).

Although the supply chain network is critical to the success of firms and the entire cluster, there are some hurdles that hinder its effectiveness. One such is the low network ties among members in both horizontal and vertical collaborations (Xue, Huang, \& Xiao, 2009). Studies conducted showed that actor integration in African supply chain networks is low, therefore affecting the performance of such networks (Akoten \& Otsuka, 2007; Msimangira, 2003). Low network ties affect information sharing and may lead to information asymmetry among upstream and downstream members (Mytelka \& Farinelli, 2000). Moreover, because of low actor and network embeddedness it prevents organisations from deriving the maximum benefit from the social capital available. Knowledge and information diffusion tends to slow down while firms find it difficult to benefit from external resources (Cooke, Uranga, \& Etxebarria, 1997). Furthermore, the inability to have a coherent supply chain network affects the collective efficiency of these enterprises (Schmitz, 1995). Trust

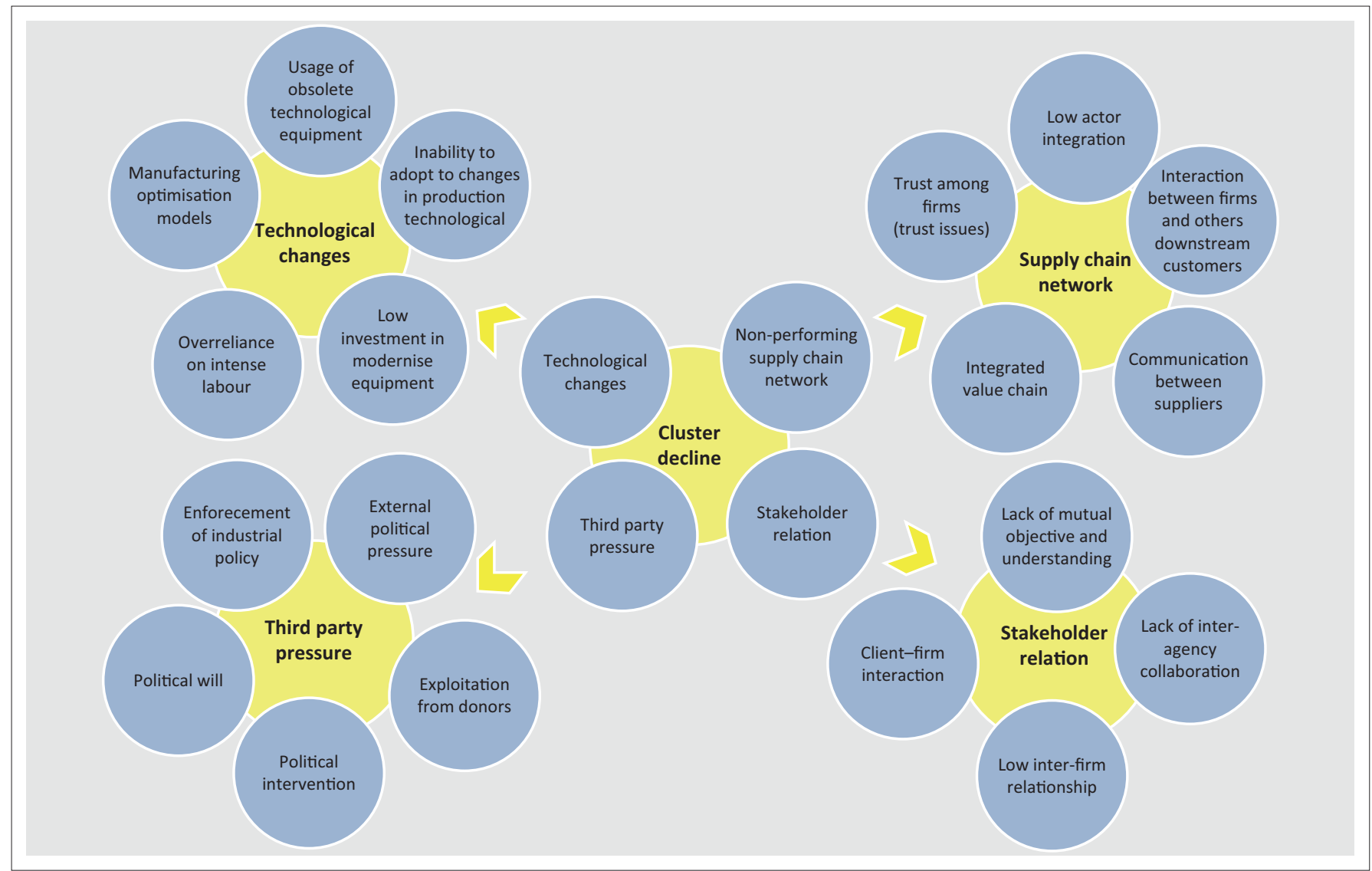

FIGURE 1: Conceptual framework. 
building among stakeholders of an ineffective supply chain network becomes difficult because of the low-interactive nature of members (Zucker, 1986).

The global supply chain network usually places pressure on the local supply chain network and affects its performance. The Wine Organisation of South Africa in 2006 revealed that disruptions of the global supply chain network adversely affected the productivity of the local wine cluster in Africa. This restricts organisations' ability to absorb the needed resources from such a network.

Cross-border trade in Africa is also restricted because of ineffective supply chain integration. Although firms within an industry cluster enjoy a low search cost, that is not the situation in Africa because of the non-existence of a comprehensive supply chain network (Fafchamps, 2000; Kinyanjui, 2000; World Bank, 2012). In view of the preceding literature, Hypothesis 4 is proposed as follows:

$\mathbf{H}_{4}$ : Actors' inability to ensure that every actor is embedded in the textile supply chain network has a negative effect on the growth and performance of this sector.

\section{Research design \\ Research method and data collection}

To achieve our stated objective, to ascertain which factors contribute to the premature decline of clusters in Africa, the study employed a mixed-methods approach. Adopting both a quantitative and qualitative approach enables researchers to gain access to empirical and soft data to address pertinent research objectives. The rationale for this method was to enable researchers to empirically analyse their theoretical variables to ascertain which factors led to the decline of the textile clusters in Ghana. As advocated by the key informant theory, Campbell (2002) elaborates on the usefulness of gaining information from relevant personnel if a meaningful contribution can be made. 'Key informants' refers to individuals within an organisation who possess sufficient knowledge about the activities of the organisation they work in. To acquire the essential data needed to test the relationship between the various latent variables and cluster decline, a field survey approach was employed to collect relevant data. Data was collected from individuals working in four out of five remaining textile-manufacturing firms (Campbell, 2002; Kothari, 2004; Galaskiwcs, 1995b; Yin, 2003, 2009).

The data collected from the field survey was stored in Microsoft Excel 2013 and later transferred to smart PLS version 13 . This statistical software was used to examine the empirical relation between third-party pressures, low stakeholder interactions and inability to adapt to changing technological trends, non-performing supply chain network and the decline of textile industry. The study adopts partial least-squares structural equation modelling (PLS-SEM) as a mode to explain the relationship between the various variables. Adopting the PLS-SEM technique is an explanatory technique that is essential for examining a phenomenon that has received limited research attention (Hair \& Lukas, 2014).

\section{Data collection}

A field survey was conducted to collect data from relevant respondents in the textile subsector of the Ghana economy. A purposive sampling technique was used to identify and select the respondents of the study. Respondents came from the four textile-manufacturing firms identified for the purpose of the study. These entities happen to be the few surviving textile clusters currently producing on a large scale in the nation. The textile industry had shrunk over the years, leading to the folding of several firms in this sector. The choice of a survey instrument was the questionnaire. The items utilised to test our theoretical Hypothesis are derived established scales: stakeholder relations (Freeman et al., 2000; Garvare \& Johansson, 2010; Heimeriks \& Duysters, 2007), technological changes (McCormick, 1998; Pavlínek \& Žížalová, 2014; Schumpeter, 1970), third-party pressures (Agola, 2016; Zimmermann, 2005) and supply chain networks (Cooke et al., 1997; Fafchamps, 2000; Narasimham \& Das, 2001; Schimtz, 1995).

In designing the questionnaire one critical element to consider is how concise and accurate it is (Craig \& Douglas, 2000; Eisennhardt, 1991; Eisenhardt \& Graebner, 2007). It should be free of any ambiguities if the research is to gain a relevant response. In this study, to deal with this issue, the questionnaire was designed using simple questions on a seven-point Likert scale. The study conducted a pilot survey using some selected individuals to ascertain whether it would be easy to understand and answer the stated questions. After the pilot survey, feedback from these individuals was used to redesign and improve the questionnaire for better understanding.

After the questionnaire design the researcher made initial contact with these clusters to discuss the objectives of the study and also to solicit their permission to use their entity for data collection. During this period, contact was made with all four entities out of the five surviving textile enterprises in Ghana. The firms agreed to our demands and allowed us to collect data from the identified key informants within the organisation. In addition data was collected from suppliers and end users (customers). A purposive sampling approach focusing on departments such as production and manufacturing, operations, engineering, finance, sales and marketing and customer service personnel was adopted to select respondents to answer the questionnaire used to test the relationship between latent constructs and cluster sustenance.

The field survey covered a period of 2 months and a total of 148 answered questionnaires were acquired. This resulted in a non-response rate of $26 \%$, compared to the total of 200 questionnaires sent out for the survey. The non-response rate may be attributed to the busy nature of the functional tasks of the personnel in the various entities. 


\section{Empirical results, analysis and discussion \\ Profile of respondents}

This section presents the profile of respondents that participated in our field survey. Table 1 shows the demography and educational background of respondents. From the table it can be seen that the study dealt with diverse individuals from multidisciplinary fields of study. This enriched the quality of data because every individual brought on board a new perspective. The availability of divergent views aided in eliminating the bias that is associated with field surveys. The respondents comprised 90 males and 58 females.

It can be seen from Table 2 that aside from suppliers and final consumers in the textile value chain, all other stakeholders were included in the data collection process. Suppliers were not included because most of the firms' suppliers were overseas, therefore making it difficult to seek their views on the subject under study. In addition, consumers tend to have a limited understanding as to which factors are contributing to the decline of the industry. Therefore, going by our key informant approach we didn't include consumers during the survey period. The categories of entities include producers of finished and semi-finished goods and distributors of textile products. Sourcing data from these diverse actors enabled the researcher to gain insight from diverse perspectives to enrich the outcome of the study. Furthermore, the category of firm within the textile value chain is presented in Table 2.

\section{Reliability and validity test}

To enable further analysis of the data acquired through the field survey, it was essential to examine the reliability and validity of the data. In accordance with PLS-SEM techniques, a composite reliability and discriminant validity test was conducted. The accepted threshold for composite reliability is 0.5 or greater (Hair, Sarstedt, Hopkins, \& Kuppelwieser, 2014; Hulland \& Ivey, 1999). The result obtained for the construct of this study had a composite reliability value of

TABLE 1: Educational background of respondents.

\begin{tabular}{lcc}
\hline Educational level & Total & Percentage \\
\hline PhD & 2 & 1.30 \\
Master's degree & 16 & 10.81 \\
Bachelor's degree & 86 & 58.10 \\
Technical qualification (HND, NVTI) & 44 & 29.79 \\
\hline
\end{tabular}

Source: Field survey 2017

HND: Higher National Diploma; NVTI: National Vocation and Technical Institute Certification.

TABLE 2: Respondents' value chain sector.

\begin{tabular}{lcc}
\hline Sector & $\begin{array}{c}\text { Number of } \\
\text { respondents }\end{array}$ & $\begin{array}{c}\text { Percentage Number of } \\
\text { respondents }\end{array}$ \\
\hline Finished product manufacturer & 79 & 53.38 \\
Semi-finished product manufacturer & 39 & 26.35 \\
Supplier & 3 & 2.02 \\
Distributor & 9 & 6.08 \\
Customer (end user) & 18 & 12.17 \\
\hline
\end{tabular}

Source: Field survey 2017. more than 0.5, suggesting that the data was reliable for further analysis. In addition, the Cronbach's alpha value obtained was 0.86 , much higher than the accepted minimum of 0.5 .

The validity of the data was further investigated using the approach proposed by Fornell and Larcker (1981). The outcome of the test showed that the average of the latent variables examined was greater than the correlation value among the diverse variables. The outcome of these tests suggested that the acquired data was accurate and proper for further empirical analysis.

\section{Collinearity test}

The variance inflation factor (VIF) was used as our measuring instrument to examine the collinearity that was associated with high correlation values among the indicator. The issue of collinearity arises when the VIF value obtained is more than 10 (Craig \& Douglas, 2000; Kline, 2015). The results obtained from this study showed that all indicators had a VIF value of less than 10 .

\section{Statistical analysis}

Table 3 presents the results of the correlation test. The outcome suggested that all variables to some extent have an effect on the survival of the textile industry. Although all the constructs examined affects the survival of the textile industry to some extent, enterprises' inability to adopt to changing technological trends makes a dent in their development. Consequently, firms that are not able to seize this advantage tend to shrink or fold because productivity is low. Besides, overhead and production costs increase with the use of obsolete production technologies. This can be seen from the multiple regression analysis in the path estimation.

Aside from the inability of textile firms to catch up with changing trends in technology, another essential factor was the non-interactivity of key stakeholders in the textile value chain. Non-availability of any form of stakeholder interaction has had dire consequences on the survival of the entire ecosystem. Judging from its regression coefficient, an increase in stakeholder relations affects the existence of the entire industry positively and vice versa. As advocated by the scholars of stakeholder theory, a well-coordinated stakeholder community enhances knowledge and value creation processes. It is therefore prudent to develop programmes and policies that will serve as a catalyst to boost cooperative activities. The social capital that this interaction builds up is

TABLE 3: Correlation results for latent variables.

\begin{tabular}{lccccc}
\hline Variables & $\mathbf{1}$ & $\mathbf{2}$ & $\mathbf{3}$ & $\mathbf{4}$ & $\mathbf{5}$ \\
\hline 1. STR & - & - & - & - & - \\
2. TECH & 0.805 & - & - & - & - \\
3. CD & 0.431 & 0.695 & - & - & - \\
4. NPSCN & 0.581 & 0.609 & 0.748 & - & - \\
5. THPP & 0.478 & 0.737 & 0.580 & 0.577 & - \\
\hline
\end{tabular}

STR: stakeholder relation; TECH: technological changes; CD: cluster decline; NPSCN: nonperforming supply chain network; THPP: third-party pressures. 


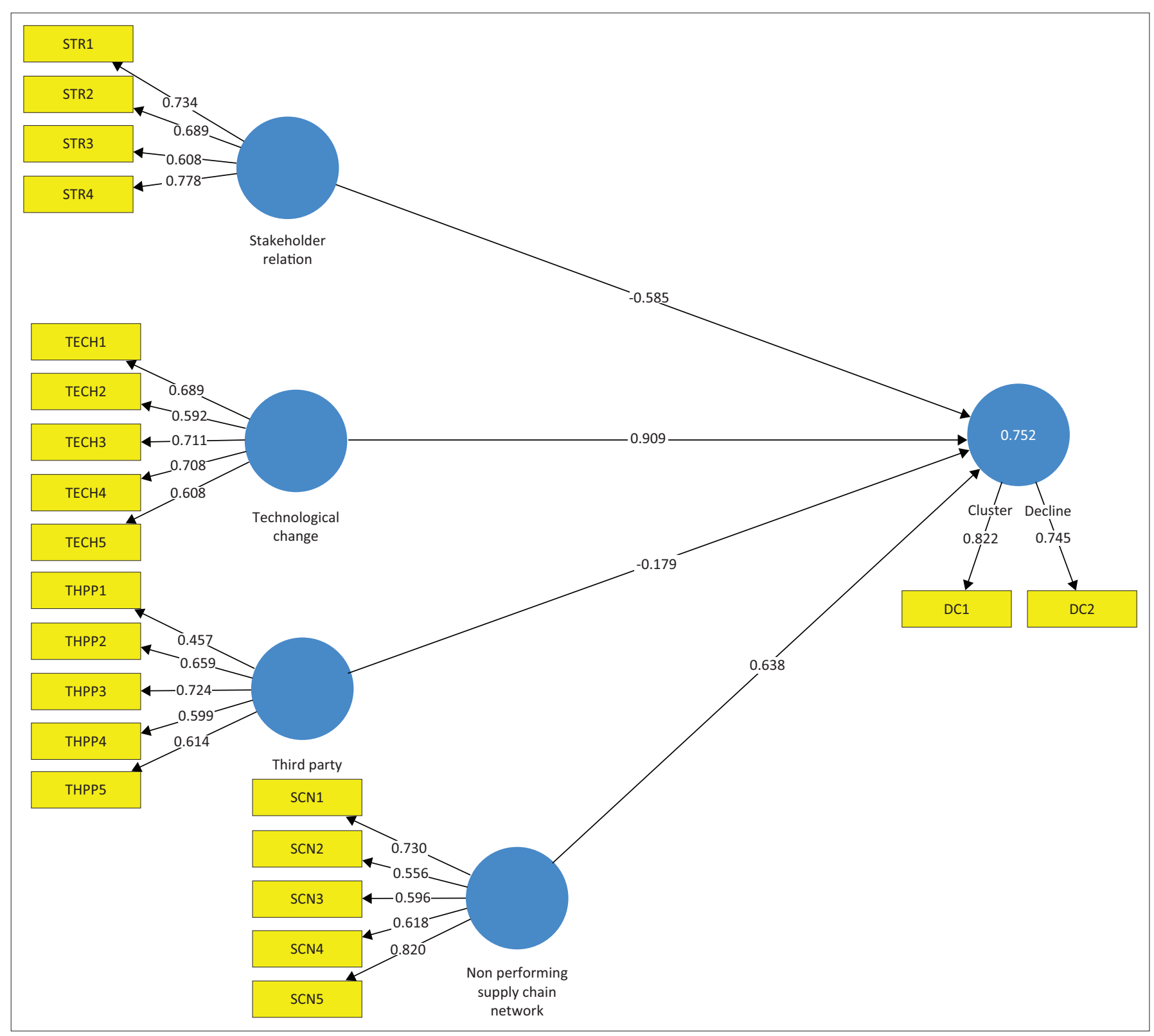

FIGURE 2: Path estimation result.

worth the pool of resources required for the consistent survival of these firms.

Again, the R-squared value of 0.752 obtained suggested an overall goodness of fit of 0.752 , suggesting that stakeholder relations, the firm's inability to adapt to changes in technology, third-party pressures and a non-performing supply chain network have adverse effects on the firm's ability to survive in the textile industry. The loose structure of the local textile supply chain network prevents firms from deriving the needed benefits with regards to sourcing of improved raw materials at comparatively cheaper cost.

Table 4 shows the outcomes of the hypotheses tested. The $t$-statistic's value was used as the unit of measurement. In accordance with Hair et al. (2014), to accept a Hypothesis it needs to have a $t$-statistic value of 1.96 or higher. Aside from Hypothesis 4, which investigated how external private and
TABLE 4: Results of Hypothesis tests.

\begin{tabular}{lccl}
\hline Hypothesis & $t$-statistic & $\boldsymbol{p}$ & Decision \\
\hline Stakeholder relations cluster decline) & 3.3158 & 0.0010 & Accepted \\
Technological change cluster decline) & 3.7483 & 0.0002 & Accepted \\
$\begin{array}{l}\text { Non-performing supply chain network } \\
\text { (cluster decline) }\end{array}$ & 4.0574 & 0.0001 & Accepted \\
Third-party pressure (cluster decline) & 1.3348 & 0.1826 & Not accepted \\
\hline
\end{tabular}

political influence led to the decline of the textile cluster, all other hypotheses were accepted. This suggests that the textile cluster's decline has been a result of low stakeholder interactions, inability to adapt to changing technological trends and non-performance of local supply chain networks.

\section{Discussion}

The finding on technological change was the most pressing factor affecting the decline of the textile industry, which contributes to studies that show that technological gaps have 
the propensity to affect the sustainability of firms or African industry clusters (McCormick et al., 2007; Porter, 1990; UNCTAD, 2012). The inability of firms to adopt and implement new, improved production technology resulted in low productivity coupled with high production costs. Obsolete technologies render local firms uncompetitive because of their inefficiency as compared with foreign firms that utilise new, innovative technologies. It is imperative for firms to invest in research and development and also in new technological machinery and equipment to boost productivity. An increase in productivity will impact the growth of these firms within this subsector of the economy.

A low level of stakeholder relations was also seen to result in the decline of the textile industry over time. The textile ecosystem is characterised by several structural holes preventing the diffusion of knowledge, technology and information. Actors within this ecosystem are not able to harness the social capital available because there is no consistent interaction between key players. The interactive nature results in formation of weak ties among members. Weak ties affect exchanges within the ecosystem, making it difficult to either gain inputs to boost the value of the product or to address grievances arising from upstream and downstream customers. The coordination activities between actors within this value chain enrich cooperation and enhance ties. To have a robust industrial subsector it is critical to have consistent and harmonious activities between the various entities at stake.

Industry clusters enjoy comprehensive supply chain networks, which results in low search cost, access to specialised skilled labour and external resources. In spite of this fact, clusters in this subregion do not enjoy such benefits because the supply chain system is not well structured. There happens to be no relationship between the diverse stakeholders in the textile value chain network. This prevents actors from identifying key issues affecting the performance of each member of the supply chain. Further, the loose structure of the supply chain results in high production costs because firms in this industry cannot attain an advantage such as low search cost. This finding also contributes to studies conducted by several scholars (Blažek, Marek, \& Květoň, 2016; Dauth \& Suedekum, 2015; Porter, 1990, 2000) on the factors affecting the African industrial environment and its antecedents. Their studies suggest that one significant challenge affecting the growth and survival of firms in Africa has been the non-availability of proper supply chain networks.

One interesting finding from the study is the non-influential nature of external pressure from donor funds and agencies as a determining factor in the collapse of the textile sector. Previous studies have suggested that foreign donors and political entities are responsible for the low development of the industrial sector through the attachment of conditionality to grants and loans offered (Zimmermann, 2005). The outcome of our study suggested that external pressure does not have a major role to play concerning the performance and sustainability of local businesses or industries and that there are serious issues to be considered in dealing with firms' survival as discussed. Regardless, it is the responsibility of every government to protect its citizenry as well as its productive ventures. In this vein, it would be appropriate for the government to have the will to provide the needed political intervention to deal with such external pressures and conditionality to ensure an enabling business environment. As the production manager of a textile company said: 'if government is committed to saving the textile industry the ministry will be more serious with pirating but as it stands now the Asian governments sometimes fund government projects and so there is lack of political will on the part of government to pursue the challenges of the textile industry as most pirated textiles are from Asia'. Inferences from this suggest that government intervention will lead to a decline in importation of copycat textiles, which happens to be a major source of concern for players in the textile industry.

\section{Managerial implications}

The findings of the study have some intriguing managerial implications that need to be addressed if textile entities are to survive in the long run to enhance productivity, employment, national and household income to aid in alleviating poverty, in a nutshell. Firms need to source new, improved knowledge and information to boost their internal capacity to improve production output. When firms gain enough relevant knowledge and information on a subject it goes a long way to affecting their performance while achieving their set targets.

Furthermore, players within this ecosystem need to create an enabling environment that promotes cooperation and cocreation. Measures should be put in place to foster interaction between the various actors within the supply chain network. This will help to deal with the structural hole associated with complex networks in addition to knowledge, information and technology spillover relevant to building and maintaining the entire supply chain network. Actors should promote interfirm relationships to boost firms' innovation capabilities and knowledge pool. The establishment of a proper supply chain network builds up social capital to augment its internal resources. Entities can utilise these resources in enriching production techniques. Improved production techniques will incur a comparatively cheaper production cost and the propensity to affect the sustenance of firms in this sector, with a ripple effect on the survival of the entire textile cluster.

\section{Conclusion and further research}

The study investigated the factors that led to industrial cluster decline in Africa, with a focus on the textile clusters in Ghana. Textile firms in Ghana have shrunk over the years in terms of productivity, revenue turnover and employee retention. The industrial sector over the years has experienced several challenges leading to the folding of several firms in this sector. Both a qualitative and quantitative approach were 
used to collect and analyse data. Data was collected from four out of the five remaining textile firms in Ghana. A total of 148 respondents answered a questionnaire designed to collect relevant data from key informants. The data collected was stored in Microsoft Excel and later transferred to statistical package software to perform further empirical analyses. PLS-SEM was used to examine the relationship between stakeholder relations, technological changes, thirdparty pressure, non-performing supply chain network and their impact on the decline of the textile industry in Ghana.

The findings of the study suggested that firms' inability to implement new technologies to boost productivity has affected the survival of this sector. Aside from the technological gaps, low level of stakeholder interaction and the ineffective supply chain network played a major role in the decline of such enterprises. One interesting finding that contradicted previous studies was the external pressure that most scholars claim negatively affects the performance of local firms was not always the case in the textile industry. Third-party pressure does not affect the survival of the textile industry significantly, unlike other dynamic factors such as non-performing supply chain network, technological lapses and lack of stakeholder relations.

Although the study has some intriguing findings, there are limitations associated with the study. The non-availability of up-to-date data in this sector limits researchers' idea about current trends and exact changes in the sector. In addition, the study focused only on textile clusters. A further study is encouraged to examine the factors that led to the decline by adding different clusters into the sample to enable researchers to ascertain whether these factors affect the decline of other traditional clusters.

\section{Acknowledgements}

Authors would like to thank the anonymous reviewer for the helpful suggestions. We are also grateful to Joseph Koku Agama and Shadrach Twumasi-Ankrah for their assistance in data collection.

\section{Competing interests}

The authors declare that they have no financial or personal relationships which may have inappropriately influenced them in writing this article.

\section{Authors' contributions}

L.A.K. conceived the article's idea. L.A.K. and O.A. collected data. L.A.K., Z.H. and O.A. were responsible for data processing and interpretation. L.A.K. and O.A. drafted the article. Critically revising the article for intellectual content was done by L.A.K., Z.H and O.A.

\section{References}

Abor, J., \& Quartey, P. (2010). Issues in SME development in Ghana and South Africa. International Research Journal of Finance and Economics, 39(39), 218-228.
Abuzeid, F. (2009). Foreign aid and the 'Big Push' theory: Lessons from sub-Saharan Africa. Stanford Journal of International Relations, 11(1), 16-23.

Adikorley, R. (2013). The textile industry in Ghana: A look into tertiary textile education and its relevance to the industry. A thesis presented to the Department of Human and Consumer Sciences, Faculty of The Patton College of Education, Ohio University. Retrieved from https://www.researchgate.net/publication/274070597

Agle, B. R., Donaldson, T., Freeman, R. E., Jensen, M. C., Mitchell, R. K., \& Wood, D. J. (2008). Dialogue: Toward superior stakeholder theory. Business Ethics Quarterly, 18(2), 153-190. https://doi.org/10.5840/beq200818214

Agola, N. O. (eds.). (2016). Japanese technological capability building and management practices for development of SMEs. In Technology transfer and economic growth in sub-Sahara African countries (pp. 63-89). Berlin: Springer.

Ahwireng-Obeng, F. (2000). The knowledge revolution and African development. Africa Insight, 30(3-4), 3-9.

Akoten, J. E., \& Otsuka, K. (2007). From tailors to mini-manufacturers: The role of traders in the performance of garment enterprises in Kenya. Journal of African Economies, 16(4), 564-595. https://doi.org/10.1093/jae/ejl047

Amélia, B., \& Lopes, J. C. (2013). The economic performance of clustered and non clustered firms along the different phases of the cluster life cycle: The Portuguese cork industry case. Working Paper 26/2013/DE/UECE/GHES. Lisbon: University of Lisbon.

Antonacopoulou, E., \& Méric, J. (2005). A critique of stake-holder theory: Management science or a sophisticated ideology of control? Corporate Governance, 5(2) 22-33. https://doi.org/10.1108/14720700510562631

Bankova, Y. (2015). Industrial clusters an incentive for a competitive regional development: A case study of selected Bulgarian industrial clusters. Trakia Journa of Science, 13(Suppl 1), 54-59. https://doi.org/10.15547/tjs.2015.s.01.011

Blažek, J., Marek, D., \& Květoň, V. (2016). The variety of related variety studies: Opening the black box of technological relatedness via analysis of inter-firm R\&D cooperative projects. Papers in Evolutionary Economic Geography, no. 1301.

Borrus, M. (2000). The resurgence of US electronics. International production networks in Asia: Rivalry or riches, International production networks in Asia, pp. 57-79.

Boudreau, K. K., \& Lakhani, K. R. (2009). How to manage outside innovation: Competitive markets or collaborative communities? MIT Sloan Management Review, 50(4), 69-75

Brettel, M., Greve, G. I., \& Flatten, T. C. (2011). Giving up linearity: Absorptive capacity and performance. Journal of Managerial Issues, 23(2), 164-189.

Brower, J., \& Mahajan, V. (2013). Driven to be good: A stakeholder theory perspective on the drivers of corporate social performance. Journal of Business Ethics, 117(2), 313-331. https://doi.org/10.1007/s10551-012-1523-z

Bruce-Amartey, J. N. R., Amissah, E. R. K., \& Safo Ankama, K. (2014). The decline of Ghana's textile industry: Its effects on textile education in Ghana. Arts and Design Studies, 22, 36-45.

Burt, R. S. (1992). Structural holes: The social structure of competition. Cambridge, MA: Harvard University Press.

Burt, R. S. (2000). The network structure of social capital. Research in Organizational Behavior, 22, 345-423. https://doi.org/10.1016/S0191-3085(00)22009-1

Burt, R. S. (2014). Structural holes and good ideas. American Journal of Sociology, 110(2), 349-399. https://doi.org/10.1086/421787

Campbell, J. (2002). A critical appraisal of participatory methods in development research. International Journal of Social Research Methodology, 5(1), 19-29. https://doi.org/10.1080/13645570110098046

Chesbrough, H. (2003). Open innovation: The new imperative for creating and profiting, from technology. Boston, MA: Harvard Business School Press.

Choi, J., \& Wang, H. (2009). Stakeholder relations \& the persistence of corporate financial performance. Strategic Management Journal, 30, 895-907.

Christopher, M., Peck, H., \& Towill, D. (2006). A taxonomy for selecting global supply chain strategies. The International Journal of Logistics Management, 17(2), $277-$ 287. https://doi.org/10.1108/09574090610689998

Cooke, P., Uranga, M. G., \& Etxebarria, G. (1997). Regional innovation systems: Institutional and organisational dimensions. Research Policy, 26(4-5), 475-491.

Coombs, W. T., \& Holladay, S. J. (2008). Comparing apology to equivalent crisis response strategies: Clarifying apology's role and value in crisis communication. Public Relations Review, 34, 252-257.

Cortright, R. N., Sandhof, K. M., \& Basilio, J. L. (2006). Skeletal muscle fat oxidation is increased in African American and white women after 10 days of endurance exercise training. Obesity, 14, 1201-1210.

Craig, S. C., \& Douglas, S. P. (2000). International marketing research (vol. 8, no. (1) pp. 6-26, 2nd edn.). Chichester: John Wiley \& Sons.

Dauth, W., \& Suedekum, J. (2015). Globalization and local profiles of economic growth and industrial change. Journal of Economic Geography, 16(5), 1007-1034. https:// doi.org/10.1093/jeg/lbv028

Dekker, P., \& Uslaner, E. M. (2001). Social capital and participation in everyday life. Community Medicine, 23(4), 194-208.

Dike, E. (1997). Structural adjustment and small-scale industrial entrepreneurs in south-eastern Nigeria. Geneva: United Nations Research Institute for Social Development.

Donaldson, T., \& Preston, L. E. (1995). The stakeholder theory of the corporation: Concepts, evidence, and implications. Academy of Management Review, 20, 65-91. 
Dyer, J. H., \& Singh, H. (1998). The relational view: Cooperative strategy and sources of inter-organizational competitive advantage. Academy of Management Review, 23, 660-679.

Eisenhardt, K. (1989). Building theories from case study research. Academy of Management Review, 14(4), 532-550. https://doi.org/10.5465/amr.1989.4308385

Eisenhardt, K. M. (1991). Better stories and better constructs: The case for rigor and comparative logic. Academy of Management Review, 16(3), 620-627. https://doi. org/10.5465/amr.1991.4279496

Eisenhardt, K. M., \& Graebner, M. E. (2007). Theory building from cases: Opportunities and challenges. Academy of Management Journal, 50(1), 25-32. https://doi. org/10.5465/amj.2007.24160888

Fafchamps, M. (2000). Ethnicity and credit in African manufacturing. Journal of Development Economics, 61(1), 205-235. https://doi.org/10.1016/S03043878(99)00068-1

Fornell, C., \& Larcker, D. (1981). Structural equation models with unobservable variables and measurement error: Algebra and statistics. Journal of Marketing Research, 18(3), 382-388. https://doi:10.2307/3150980

Freeman, C. (1987). Technology policy and economic performance: Lessons from Japan. London: Frances Printer.

Freeman, C. (2002). Continental national and sub-National innovation systems Complementary and economic growth. Research Policy, 31, 191-211.

Freeman, R. E. (1984). Strategic management: A stakeholder approach. Boston, MA Pitman.

Freeman, R. E., \& Reed, D. L. (1983). Stockholders and stakeholders: A new perspective on corporate governance. California Management Review, 25(3), 88-106. https:// doi.org/10.2307/41165018

Freeman, R. E., Wicks, A. C., \& Parmar, B. (2004). Stake-holder theory and 'The corporate objective revisited'. Organization Science, 15(3), 364-369. https://doi. org/10.1287/orsc.1040.0066

Galaskiewicz, J. (1995a). An urban grants economy revisited: Company contributions in the twin cities, 1979-1981, 1987-89. Minneapolis: Department of Sociology, University of Minnesota.

Galaskiewicz, J. (1995b). The making of organizational reputations. In Annual Meeting of the Academy of Management, August 6-9, 1995, n.p., Paper presented at the of the Academy of Management, August $6-9,1995$,
Academy of Management Meetings, Vancouver, BC.

Ganesan, S., Malter, A. J., \& Rindfleisch, A. (2005). Does distance still matter? Geographic proximity and new product development. Journal of Marketing, 69(4), 44-60. https://doi.org/10.1509/jmkg.2005.69.4.44

Garvare, R., \& Johansson, P. (2010). Management for sustainability - A stakeholde theory. Total quality management, 21(7), 737-744. https://doi.org/10.1080/1478 3363.2010.483095

Gereffi, G., \& Lee, J. (2016). Economic and social upgrading in global value chains and industrial clusters: Why governance matters. Journal of Business Ethics, 133(1) 25-38. https://doi.org/10.1007/s10551-014-2373-7

Ghana Web. (2017a). GTP lays off over 200 workers for mechanisation. Retrieved from http://www.ghanaweb.com/GhanaHomePage/business/GTP-lays-off-over-200workers-for-mechanisation-502134

Ghana Web. (2017b) Textile industry in dire straits. Retrieved from https://www. ghanaweb.com/GhanaHomePage/business/Textile-industry-in-dire-straits-513817

Gordon, I. R., \& McCann, P. (2000). Industrial clusters: Complexes, agglomeration and/ or social networks?. Urban Studies, 37(3), 513-532. https://doi.org/10.1080/ 0042098002096

Granovetter, M. S. (1973). The strength of weak ties. American Journal of Sociology, $78,1360-1380$

Grunig, J. E., \& Huang, Y.-H. (2000). From organizational effectiveness to relationship indicators: Antecedents of relationships, public relations strategies, and relationship outcomes. In J. Ledingham \& S. Bruning (Eds.), Public relations as relationship management. A relational approach to the study and practice of public relations, (pp. 23-54). Mahwah, NJ: Lawrence Erlbaum Associates.

Gulati, R. (1995). Social structure and alliance formation patterns: A longitudinal analysis. Administrative Science Quarterly, 40(4), 619-652. doi:10.2307/2393756

Gulati, R., \& Nickerson, J. A. (2008). Interorganizational trust, governance choice, and exchange performance. Organization Science, 19(5), 688-708.

Hair, J. F. Jr., \& Lukas, B. (2014). Marketing research (vol. 2). Sydney: McGraw-Hill Education.

Hair, Jr., F., Sarstedt, J., Hopkins, M., \& Kuppelwieser, L. G. (2014). Partial least squares structural equation modeling (PLS-SEM) an emerging tool in business research. European Business Review, 26(2), 106-121. https://doi.org/10.1108/EBR-102013-0128

Hansen, M. W., Pedersen, T., \& Petersen, B. (2009). MNC strategies and linkage effects in developing countries. Journal of World Business, 44, 121-130.

Harland, C. (1996). Supply network strategies the case of health supplies. European Journal of Purchasing \& Supply Management, 2(4), 183-192. https://doi. org/10.1016/S0969-7012(96)00014-7

Harrison, J. S., \& Weaver, G. (2013). Stakeholder theory, value, and firm performance. Business Ethics Quarterly, 23(1), 97-124. https://doi.org/10.5840/beq20132314

He, Z., \& Rayman-Bacchus, L. (2010). Cluster network and innovation under transitional economies. Chinese Management Studiesm, 4(4), 360-384. https:// doi.org/10.1108/17506141011094145

Heimeriks, K., \& Duysters, G. (2007). Alliance capability as a mediator between experience and alliance performance: An empirical investigation into alliance capability development process. Journal of Management Studies, 44(1), 25-49. https://doi.org/10.1111/j.1467-6486.2006.00639.x
Hillebrand, B., Driessen, P. H., \& Koll, O. (2015). Stakeholder marketing: Theoretical foundations and required capabilities. Journal of the Academy of Marketing Science, 43(4), 411-428. https://doi.org/10.1007/s11747-015-0424-y

Hillman, A. J., \& Keim, G. D. (2001). Shareholder value, stake- holder management, and social issues: What's the bottom line?. Strategic Management Journal, 22, 125-139.

Horner, R. (2014). Postgraduate encounters with sub-disciplinary divides: Entering the economic/development geography trading zone. Area, 46(4), 435-442. https:// doi.org/10.1111/area.12130

Humphrey, J., \& Schmitz, H. (2002). How insertion in global value chains affects upgrading in industrial clusters. Regional Studies, 36(9), 1017-1027. https://doi. org/10.1080/0034340022000022198

Hulland, J., \& Ivey, R. (1999). Use of partial least squares (PLS) in strategic management research: A review of four recent studies. Strategic Management Journal, 20(2), 195-204.

Kilby, C., \& Axel, D. (2010). The impact of aid on growth revisited: Do donor motives matter?. Economics Letters, 107(3), 338-340. https://doi.org/10.1016/j.econlet. 2010.02.015

Kinyanjui, M. N. (2000). Tapping opportunities in Jua Kali enterprise clusters: The case of Ziwani and Kigandaini. Working paper no. 525. Nairobi: Institute for Development Studies, University of Nairobi.

Kirankabeş, M. C., \& Arik, M. (2014). Industrial clustering approach in regional development: The case of Turkey. Journal of Applied Business and Economics, 16(3), 135-151.

Kothari, C. (2004). Research methodology, methods and techniques (2nd edn.). New Delhi: New Age International Ltd.

Krackhardt, D., \& Porter, L. W. (1986). The snowball effect: Turnover embedded in communication networks. Journal of Applied Psychology, 71(1), 50. https://doi. org/10.1037/0021-9010.71.1.50

Krugman, P. (1991). Geography and trade. Cambridge, MA: MIT Press.

Kurata, Y. B., Matias, A. C., \& Grepo Lorelie, C. (2015). Manpower utilization in the hotdog meat processing production of a meat processing company. Procedia Manufacturing, 3, 340-345. https://doi.org/10.1016/j.promfg.2015.07.168

Kurniawan, Y., Abdullah, W. M. W., Som, H. M., \& Parasuraman, B. (2013). Employing industrial cluster concept as a strategy to improve small industries in Kelantan, Malaysia. International Refereed Research Journal, 4(19), 19-24.

Latour, B. (2005). Reassembling the social: An introduction to actor-network-theory. Oxford: Oxford University Press.

Levin, D. Z., Cross, R., \& Abrams, L. C. (2002). He strength of weak ties you can trust: The mediating role of trust in effective knowledge transfer. Academy of Management Proceedings, 2002(1), D1-D6. https://doi.org/10.5465/apbpp.2002.7517527

Lindberg, M., \& Säll, L., The contested cluster concept: Paradoxical pathways to Nordic innovations. International Journal of Innovation Science, 5(1), 11-20.

Luoma-aho, V., \& Vos, M. (2009). Monitoring the complexities: Nuclear power and public opinion. Public Relations Review, 35(2), 120-122. https://doi.org/10.1016/ j.pubrev.2009.01.013

Mano, Y., Iddrisu, A., Yoshino, Y., \& Sonobe, T. (2012). How can micro and small enterprises in sub-Saharan Africa become more productive? The impacts of experimental basic managerial training. World Development, 40(3), 458-468. http://doi.org/10.1016/j.worlddev.2011.09.013

Martin, R. L., \& Sunley, P. J. (2011). Conceptualizing cluster evolution: Beyond the life cycle model. Regional Studies, 45(10), 1299-1318. https://doi.org/10.1080/0034 3404.2011.622263

Mattoon, R., \& Wang, N. (2014). Industry clusters and economic development in the Seventh District's largest cities. Economic Perspectives, 38(2), 52-67.

McCann, B. T., Reuer, J. J., \& Lahiri, N. (2016). Agglomeration and the choice between acquisitions and alliances: An information economics perspective. Strategic Management Journal, 37(6), 1085-1106. https://doi.org/10.1002/smj.2387

McCormick, D., Kinyanjui, M. N., \& Ongile, G. (1997). Growth and Barriers to Growth Among Nairobi's Small- and Medium-Sized Garment Producers. World Development, 25(7), 1095-1110.

McCormick, D. (1998). Enterprise clusters in African: On the way to industrialisation? IDS Discussion Paper 366. Brighton: Institute of Development Studies.

McCormick, D. (1999). African enterprise clusters and industrialisation: Theory and reality. World Development, 27(9), 1531-1552. https://doi.org/10.1016/S0305750X(99)00074-1

McCormick, D., Gebre-Egeziabher, T., \& Kuzilwa, J. (2009). Industrializing Africa in the era of globalization: Challenges to clothing and footwear. Nairobi: University the era of globaliza
of Nairobi Press.

McCormick, D., Mitullah, W., \& Manga, E. (2007). Extent and forms of donor proliferation and coordination in Kenya: The case of inclusive industrialisation and governance reform 2000-2005. In press no. 546. Nairobi: Institute for Development Studies, University of Nairobi.

Menzel, M. P., \& Fornahl, D. (2009). Cluster life cycles-dimensions and rationales of cluster evolution. Industrial and Corporate Change, 19(1), 205-238. https://doi. org/10.1093/icc/dtp036

Morosini, P. (2004). Industrial clusters, knowledge integration and performance. World Development, 32(2), 305-326. https://doi.org/10.1016/j.worlddev.2002.12.001

Mowery, D. C. (2009). Plus can change: Industrial R\&D in the 'third industrial revolution'. Industrial and Corporate Change, 18(1), 1-50. https://doi.org/10.1093/icc/dtn049

Msimangira, K. A. B. (2003). Purchasing and supply chain management practices in Botswana. Supply Chain Management: An International Journal, 8(1), 7-11. https://doi.org/10.1108/13598540310463305 
Mytelka, L. (2000). Local systems of innovation in a globalized world economy. Industry and Innovation, 7(1), 15-32. https://doi.org/10.1080/713670244

Mytelka, L. (2004). Catching up in new wave technologies. Oxford Development Studies, 32(3), 389-405. https://doi.org/10.1080/1360081042000260593

Mytelka, L., \& Farinelli, F. (2000). Local clusters, innovation systems and sustained competitiveness. UNU/INTECH Discussion Paper. United Nations University, 4-6th September.

Mytelka, L. K., \& Oyelaran-Oyeyinka, B. (2000). Systems of innovation, natura resources and competitiveness in Africa. In A paper presented to the Working Group on Food Security and Technology, Economic Commission on Africa (ECA), Addis Ababa, Ethiopia, April.

Narasimham, R., \& Das, A. (2001). The impact of purchasing integration and practices on manufacturing performance. Journal of Operations Management, 19(5), 593-609. https://doi.org/10.1016/S0272-6963(01)00055-9

Osei, B.-N., Tutu, K. A., \& Sowa, N. K. (1993). Impact of structural adjustment on smallscale enterprises in Ghana. In A. H. J. Helmsing, \& T. H. Kolstee (Eds.), Structura adjustment, financial policy and assistance programmes in Africa (pp. 53-70) London: IT Publications.

Otchere, A. F., Annan, J., \& Anin, E. K. (2013). Achieving competitive advantage through supply chain integration in the cocoa industry: A case study of Olam Ghana Limited and Produce Buying Company Limited. International Journal of Business and Social Research, 3(2), 131-145.

Outlook, A. E. (2012). Special theme: Promoting youth employment. Paris: Paris African Development Bank and OECD Development Centre.

Oyelaran-Oyeyinka, B. (2001). Networks and linkages in African manufacturing cluster: A Nigerian case study. Networks, 5, 3-55.

Oyelaran-Oyeyinka, B. (2011). Nigeria yesterday and tomorrow: An economic perspective of industrial regress, dreams and visions, Ibadan, Nigeria: Lead City University Ibadan.

Oyelaran-Oyeyinka, B., \& McCormick, D. (2007). Industrial clusters and innovation systems in Africa, Tokyo: United Nations University Press.

Page, J. (2012). Can Africa industrialise?. Journal of African Economies, 21(Suppl 2), 83-124. http://doi.org/10.1093/jae/ejr045

Patel, V. K., Manley, S. C., Hair, J. F., Ferrell, O. C., \& Pieper, T. M. (2016). Is stakeholder orientation relevant for European firms?. European Management Journal, 34(6) 650-660. https://doi.org/10.1016/j.emj.2016.07.001

Pavlínek, P., \& Žižalová, P. (2014). Linkages and spillovers in global production networks: Firm-level analysis of the Czech automotive industry. Journal of Economic Geography, 16(2), 331-363. https://doi.org/10.1093/jeg//bu041

Perez, C. (2009). Technological revolutions and techno-economic paradigms. Cambridge Journal of Economics, 34(1), 185-202. https://doi.org/10.1093/cje/ bep051

Pfarrer, M. D. (2010). What is the purpose of the firm?: Shareholder and stakeholder theories, Good business: Exercising effective and ethical leadership (pp. 86-93). New York: Routledge.

Porter, M. (1990). The competitive advantage of nations. New York: The Free Press.

Porter, M. E. (2000). Location, competition, and economic development: Local cluster in a global economy. Economic Development Quarterly, 14(1), 15-34. https://doi. org/10.1177/089124240001400105

Prim, A. L., Amal, M., \& Carvalho, L. (2016). Regional cluster, innovation and export performance: An empirical study. BAR - Brazilian Administration Review, 13(2), 1-26. https://doi.org/10.1590/1807-7692bar2016160028

Purwanto, U. S., Kamaruddin, S., \& Mohamad, N. (2015). The role of industrial clustering and manufacturing flexibility in achieving high innovation capability and operational performance in Indonesian manufacturing SMEs. Industrial Engineering and Management Systems, 14(3), 236-247. https://doi.org/10.7232/ iems.2015.14.3.236

Quartey, P. (2006). The impact of migrant remittances on household welfare in Ghana AERC research paper 158. Nairobi: AERC.

Quartey, P., \& Abor, J. (2011). Do Ghanaians prefer imported textiles to locally manufactured Ones? Modern Economy, 2, 54-61. https://doi.org/10.4236/ me.2011.21009

Rappaport, A. (1986). Creating shareholder value: A guide for managers \& investors. New York: The Free Press.

Rogers, E. M. (2003). Innovation of adoption (5th edn.). New York: The Free Press.

Sang, H., Guyo, W., \& Odhiambo, R. (2014). The moderating role of employee engagement on the relationship between labour productivity with training and career development. International Journal of Business and Behavioral Sciences, $4(7), 12-22$.

Saxenian, A. (1996). Regional networks: Industrial adaptation in Silicon Valley and route 128. Cityscape: A Journal of Policy Development and Research, 2(2), 41-60.

Scandelius, C., \& Cohen, G. (2016). Achieving collaboration with diverse stakeholders The role of strategic ambiguity in CSR communication. Journal of Business Research, 69(9), 3487-3499. https://doi.org/10.1016/j.jbusres.2016.01.037

Scheel, C. (2002). Knowledge clusters of technological innovation systems. Journal of Knowledge Management, 6(4), 356-367. https://doi.org/10.1108/ 13673270210440866

Schmitz, H. (1995). Collective efficiency: Growth path for small scale industry. The Journal of Development Studies, 31(4), 529-566. https://doi.org/10.1080/ 00220389508422377
Schmitz, H., \& Nadvi, K. (1999). Clustering and industrialization: Introduction World Development, 27(9), 1503-1514. https://doi.org/10.1016/S0305-750X(99) 00072-8

Schumpeter, J. A. (1920). Max Webers Work. Joseph A. Schumpeter: The economics and sociology of capitalism. Berlin: Duncker and Humboldt.

Schumpeter, J. A. (1970). Das Wesen des Geldes, edited by F. K. Mann. Göttingen: Vandenhoeck \& Ruprecht.

Shing, K., Kenneth, C., \& Lynn, C. (2016). The role of social networks theory and methodology for project stakeholder management. Procedia - Socia and Behavioral Sciences, 226, 372-380. https://doi.org/10.1016/j.sbspro.2016. 06.201

Singleton, Jr. R., Straits, B. C., Straits, M. M., \& McAllister, R. J. (1988). Approaches to social research. New York, NY: Oxford University Press.

Spencer, G. M., Vinodrai, T., Gertler, M. S., \& Wolfe, D. A. (2010). Do clusters make a difference? Defining and assessing their economic performance. Regional Studies, 44(6), 697-715. https://doi.org/10.1080/00343400903107736

Spencer, J. W. (2008). The impact of multinational enterprise strategy on indigenous enterprises: Horizontal spillovers and crowding out in developing countries. Academy of Management Review, 33(2), 341-361. https://doi.org/10.5465/ amr.2008.31193230

Sturgeon, T. J. (2003). What really goes on in Silicon Valley? Spatial clustering and dispersal in modular production networks. Journal of Economic Geography, 3(2), disp-225. https://doi.org/10.1093/jeg/3.2.199

Sturgeon, T., Van Biesebroeck, J., \& Gereffi, G. (2008). Value chains, networks and clusters: Reframing the global automotive industry. Journal of Economic Geography, 8, 297-321. https://doi.org/10.1093/jeg/lbn007

Tsai, P. C. F., Yeh, C. R., Wu, S.-L., \& Huang, I.-C. (2005). An empirical test of stakeholder influence strategy models: Evidence from business downsizing in Taiwan International Journal of Human Resource Management, 16, 1862-1885. https:// doi.org/10.1080/09585190500298479

Tsai, W. (2001). Knowledge transfer in intraorganizational networks: Effects of network position and absorptive capacity on business unit innovation and performance. Academy of Management Journal, 44(5), 996-1004.

UNCTAD. (2001). World investment report 2001: Promoting linkages. New York United Nations.

UNCTAD. (2012). World investment report 2012: Towards a new generation of investment policies. New York: United Nations.

UNCTAD. (2003). World investment report. Geneva: United Nations Conference on Trade and Development.

UNIDO. (1999). African industry 2000: The challenge of going global. Vienna: UNIDO.

UNU-Wider. (2015). Learning to compete; Industrial clusters: Who benefits?. New York: UNU - WIDER.

Vitek, W. (1999). Capability traps? The mechanisms of persistent implementation failure. Working Paper 234. Washington, DC: CGD.

Volberda, H. W., \& Van den Bosch, F. A. J. (2005). Rethinking innovation: Management and organization matter most, In The Copenhagen Conference on Strategic Management 2005, 14-15 December, 2005 (pp. 1-36) Copenhagen, Denmark.

Wang, H. M. D., \& Sengupta, S. (2016). Stakeholder relationships, brand equity, firm performance: A resource-based perspective. Journal of Business Research, 69(12), 5561-5568. https://doi.org/10.1016/j.jbusres.2016.05.009

Weng, D. H. (2016a). Beyond interfirm dissimilarity: The impact of status difference on unplanned alliance dissolution. Academy of Management Proceedings, 2016(1), unplanned alliance dissolution. Academy of Management Procec
16504,10510 , Academy of Management, Briarcliff Manor, NY.

Weng, X. (2016b). The research of logistics industrial cluster: Concept, characteristic and function. International Journal of Business and Economics Research, 5(3), 55-60. https://doi.org/10.11648/j.ijber.20160503.14

Williamson, O. E. (1985). The economic institutions of capitalism: Firms, markets, relational contracting. New York: Free Press.

Wines of South Africa (WOSA). (2006). 2006 a tough year for SA wine industry. Retrieved from http://www.wosa.co.za/sa/news_article.php?id=207

Wong, K. K. K. (2013). Partial least squares structural equation modeling (PLS-SEM) techniques using SmartPLS. Marketing Bulletin, 24(1), 1-32.

Wood, D., \& Jones, R. (1995). Stakeholder mismatching: A theoretical problem in empirical research on corporate social performance. International Journal of Organizational Analysis, 3(3), 229-267. https://doi.org/10.1108/eb028831

World Bank. (2012). Information and communications for development 2012: Maximizing mobile, World Bank Publications, Washington, DC.

World Development. (1999). Special issue: Industrial clusters in developing countries. World Development, 27(9), 1503-1734.

$\mathrm{Wu}, \mathrm{X}$. (2007). Stakeholder identifying and positioning (SIP) models: From Google's operation in China to a general case-analysis framework. Public Relations Review, 33(4), 415-425. Retrieved from www.internetworldstats.com

Xue, X., Biqing, H., \& Tianyuan, X. (2009). The study of inter-organizational collaboration by cluster supply chain. In Proceedings of the 2009 IEEE International Conference on Automation and Logistics, 5-7 August 2009 (pp. 124-129) Shenyang, People's Republic of China.

Yamin, M., \& Sinkovics, R. R. (2008). Infrastructure or foreign direct investment? An examination of the implications of MNE strategy for economic development. Journal of World Business, 44(2), 144-157.

Yin, R. (2003). Case study research: Design and methods. Thousand Oaks, CA: Sage. 
Yin, R. K. (2009). Case study research: Design and methods. Thousand Oaks, CA: Sage.

Zander, U., \& Kogut, B. (1995). Knowledge and the speed of the transfer and imitation of organizational capabilities: An empirical test. Organization Science, 6(1), 76-92. https://doi.org/10.1287/orsc.6.1.76
Zimmermann, F. (2005). The international aid system: A question of perspective. OECD Development Centre Policy Insights, No. 12. Paris: OECD Publishing. https://doi. org/10.1787/246252820650

Zucker, L. G. (1986). The production of trust: Institutional sources of economic structure, 1840-1920. Research in Organizational Behavior, 8, 53-111. 